\title{
Pematahan Dormansi Benih Kelapa Sawit (Elaeis guineensis Jacq.) dengan Perendaman dalam Air Panas dan Variasi Konsentrasi Ethephon
}

\section{Dormancy Breaking of Oil Palm (Elaeis guineensis Jacq.) Seeds by Hot Water Soaking and Variation of Ethephon Concentration}

\author{
Belladina Farhana $^{1}$, Satriyas Ilyas ${ }^{*}$, Lalu Firman Budiman ${ }^{2}$
}

${ }^{1}$ Departemen Agronomi dan Hortikultura, Fakultas Pertanian, Institut Pertanian Bogor

(Bogor Agricultural University), J1. Meranti, Kampus IPB Darmaga, Bogor 16680, Indonesia

Telp.\&Faks.62-251-8629353 e-mail agronipb@indo.net.id

${ }^{2}$ Reasearch and Development PT Astra Agro Lestari Tbk. Desa Pandu Senjaya, Kec.Pangkalan Lada, Pangkalan

Bun, Kalimantan Tengah 74111, PO Box 14

\begin{abstract}
This research was held from April to July 2012, located in the seed processing unit of PT Astra Agro Lestari Tbk, Central Borneo. The study consisted of three experiments, the first experiment to determine the effect of water temperature and immersion intensity of seed germination. The first experiment used completely randomized design (CRD) factorial with two factors, water temperature: $27,60,70,80,90^{\circ} \mathrm{C}$ and immersion intensity: $1 \times 24$, $2 \times 24,3 \times 24$ hours. The second experiment used a single factor of CRD namely ethephon concentration: 0, 0.4, $0.8,1.2,1.6 \%$. The third experiment was a continuation from the second experiment with the adding heat drying treatment during a week. The result showed that $3 \times 24$ hours soaking treatment in $80^{\circ} \mathrm{C}$ hot water increased the germination, soaking in ethephon $0.4 \%$ inhibited radicle growth resulted abnormal seedlings. Soaking seed in $80^{\circ} \mathrm{C}$ hot water for $3 \times 24$ hours and followed by ethephon and then heat drying treatment for a week increased germination (52.0\% maximum growth potential) but still ineffective to break seed dormancy.
\end{abstract}

Key Words: breaking dormancy, ethephon, hot water treatment, oil palm seeds

\section{ABSTRAK}

Penelitian ini dilaksanakan sejak bulan April hingga Juli 2012 di unit pemrosesan benih PT Astra Agro Lestari Tbk, Kalimantan Tengah. Penelitian terdiri atas tiga percobaan yang dilakukan secara berseri. Percobaan I dilakukan untuk mengetahui pengaruh suhu air dan intensitas perendaman terhadap perkecambahan benih. Percobaan I menggunakan Rancangan Acak Lengkap (RAL) faktorial dengan dua faktor yaitu suhu air: 27, 60, 70, 80, 90 ${ }^{\circ} \mathrm{C}$ dan intensitas perendaman: 1x24, 2x24, 3x24 jam. Percobaan II menggunakan RAL satu faktor yaitu konsentrasi ethephon: 0, 0.4, 0.8, 1.2, 1.6\%. Pada percobaan III, benih terebih dahulu direndam dalam air panas suhu $80^{\circ} \mathrm{C}$ selama $3 \times 24$ jam sebelum direndam dalam ethephon, lalu diakhiri dengan pemanasan kering $39-40^{\circ} \mathrm{C}$ selama 1 minggu. Hasil menunjukkan bahwa perendaman dalam air suhu $80^{\circ} \mathrm{C}$ selama $3 \times 24 \mathrm{jam}$ meningkatkan perkecambahan benih, perendaman dalam ethephon $0.4 \%$ menghambat pertumbuhan radikula sehingga kecambah tumbuh tidak normal. Perlakuan perendaman dalam ethephon $0.4 \%$ yang didahului dengan perendaman menggunakan air panas $80^{\circ} \mathrm{C}$ selama $3 \times 24$ jam dan diakhiri dengan pemanasan kering meningkatkan perkecambahan benih (potensi tumbuh maksimum 52.0\%) namun belum efektif untuk mematahkan dormansi benih.

Kata kunci: pematahan dormansi, ethepon, perlakuan air panas, benih kelapa sawit

\section{PENDAHULUAN}

Kelapa sawit (Elaeis gunieensis Jacq.)

\footnotetext{
* Penulis untuk korespondensi. e-mail: satriyas252@gmail.com
}

merupakan salah satu komoditi andalan Indonesia yang perkembangannya sangat pesat. Permintaan benih (kecambah) kelapa sawit per tahun sekitar 100120 juta kecambah, namun produsen benih yang ada 
hanya mampu menyediakan 60-70 juta kecambah per tahun.

Proses pengecambahan benih kelapa sawit cukup sulit karena benih memiliki kuit yang keras sehingga bersifat dorman. Adanya kondisi dormansi ini menyebabkan benih harus diberi perlakuan untuk mematahkan dormansi. Proses pengecambahan benih kelapa sawit yang bermutu memerlukan waktu sekitar 3 bulan dengan metode pemanasan kering suhu $40^{\circ} \mathrm{C}$.

Metode lain yang dapat digunakan untuk mematahkan dormansi benih yaitu dengan merendam benih dalam air panas. Perlakuan air panas dengan suhu $60^{\circ} \mathrm{C}$ mampu mematahkan dormansi benih Casuarina equisetifolia Lum. dan meningkatkan daya berkecambahnya (Kesaulija, 1979). Ani (2006) melaporkan bahwa perendaman benih lamtoro (Leucaena leucocephala) dalam air dengan suhu awal $60-70^{\circ} \mathrm{C}$ selama $10-12$ menit mampu mematahkan dormansi dan menghasilkan daya berkecambah sebesar $75 \%$. Khaeruddin (1994) menyatakan bahwa benih akasia yang direndam air panas dengan suhu $80^{\circ} \mathrm{C}$ kemudian didiamkan selama 24 jam sampai air rendamannya dingin, juga dapat meningkatkan daya berkecambah dan mempercepat pertumbuhan bibit.

Penggunaan ethephon juga mampu mematahkan dormansi karena ethephon mampu merangsang aktivasi enzim untuk perkecambahan. Herrera et al. (1998) melaporkan bahwa penggunaan ethephon dengan konsentrasi $0.6 \%$ selama 48 jam pada benih kelapa sawit mampu menghasilkan perkcambahan sebesar $88 \%$ jika didahului dengan perendaman menggunakan asam sulfat 98\% selama 10 menit. Kombinasi penggunaan hidrogen sianamida $1.5 \%$ dan ethephon $1.2 \%$ tanpa perlakuan skarifikasi sebelumnya mampu menghasilkan 60\% daya berkecambah benih kelapa sawit.

Tujuan penelitian ini adalah untuk mengetahui pengaruh perendaman dalam air panas dan konsentrasi ethephon terhadap pematahan dormansi benih kelapa sawit serta mendapatkan metode perkecambahan yang lebih cepat dibanding metode konvensional.

\section{BAHAN DAN METODE}

Penelitian dilaksanakan di unit pemrosesan benih kelapa sawit PT Astra Agro Lestari Tbk, Kalimantan Tengah. Penelitian ini dilaksanakan mulai bulan April hingga Juli 2012.

Benih kelapa sawit yang digunakan dalam penelitian ini yaitu varietas DxP Yangambi. Benih kelapa sawit yang digunakan telah disimpan selama 3 bulan di ruang penyimpanan dengan suhu $18^{\circ} \mathrm{C}$. Bahan yang digunakan yaitu zat pengatur tumbuh ethephon, aquades, alkohol, fungisida Dithane, wadah pengecambah, plastic, dan kertas label. Alat yang digunakan yaitu gelas ukur, gelas kimia, pengaduk kaca, termometer, oven, cawan, timbangan, penggaris, tempat perkecambahan, tempat pemanasan kering, dan peralatan pengamanan dalam laboratorium.

Percobaan terdiri atas tiga tahap. Percobaan I adalah penentuan suhu air dan intensitas perendaman benih kelapa sawit. Percobaan II adalah penentuan konsentrasi ethephon yang optimum, dan percobaan III adalah pengaruh perendaman dalam berbagai konsentrasi ethephon yang didahului dengan perendaman dalam air panas suhu $80^{\circ} \mathrm{C}$ selama $3 \times 24$ jam dan diakhiri dengan pemanasan kering selama 1 minggu terhadap perkecambahan benih kelapa sawit

Percobaan I, yaitu penentuan suhu air dan intensitas perendaman benih kelapa sawit bertujuan untuk menentukan suhu air dan intensitas perendaman yang digunakan untuk merendam benih kelapa sawit. Percobaan ini dilakukan menggunakan Rancangan Acak Lengkap (RAL) faktorial yang terdiri atas dua perlakuan. Faktor pertama suhu air terdiri atas lima taraf yaitu $\mathrm{P} 0$ : suhu air tanpa pemanasan $\left(27^{\circ} \mathrm{C}\right), \mathrm{P} 1$ : suhu air awal $60^{\circ} \mathrm{C}, \mathrm{P} 2$ : suhu air awal $70^{\circ} \mathrm{C}, \mathrm{P} 3$ : suhu air awal $80^{\circ} \mathrm{C}$, dan $\mathrm{P} 4$ : suhu air awal $90^{\circ} \mathrm{C}$. Faktor kedua, intensitas perendaman terdiri atas empat taraf yaitu I0: tanpa perendaman, I1: 1×24 jam (satu kali perendaman selama 24 jam), I2: $2 \times 24$ jam (dua kali perendaman dengan masing-masing perendaman dilakukan selama 24 jam), dan I3: $3 \times 24$ jam (tiga kali perendaman dengan masing-masing perendaman dilakukan selama 24 jam). Tiap perlakuan diulang sebanyak tiga kali sehingga terdapat 60 satuan percobaan.

Percobaan II yaitu penentuan konsentrasi ethephon yang optimum, dilakukan berdasarkan hasil dari percobaan I. Perlakuan terbaik pada percobaan I digunakan sebagai perlakuan pendahuluan pada percobaan II dan III. Percobaan menggunakan Rancangan Acak Lengkap (RAL) satu faktor yaitu konsentrasi ethephon yang terdiri atas E0: ethephon $0 \%$, E1: ethephon $0.4 \%$, E2: ethephon $0.8 \%$, E3: ethephon $1.2 \%$, dan E4: ethephon 1.6\%. Tiap kombinasi perlakuan diulang sebanyak lima kali sehingga terdapat 25 satuan percobaan.

Percobaan III yaitu pengaruh perendaman dalam berbagai konsentrasi ethephon yang didahului dengan perendaman dalam air panas suhu $80^{\circ} \mathrm{c}$ selama $3 \times 24$ jam dan diakhiri dengan pemanasan kering selama 1 minggu terhadap perkecambahan benih kelapa sawit. Percobaan ini menggunakan Rancangan Acak Lengkap (RAL) satu faktor yaitu perlakuan pematahan dormansi yang terdiri atas lima perlakuan yaitu: T1 (perendaman pada suhu $80{ }^{\circ} \mathrm{C}$ selama $3 \times 24$ 
jam + pemanasan kering selama 1 minggu), T2 (perendaman pada suhu $80{ }^{\circ} \mathrm{C}$ selama $3 \times 24$ jam + ethephon $0.4 \%+$ pemanasan kering selama 1 minggu), $\mathrm{T} 3$ (perendaman pada suhu $80{ }^{\circ} \mathrm{C}$ selama $3 \times 24$ jam + ethephon $0.8 \%$ + pemanasan kering selama 1 minggu), $\mathrm{T} 4$ (perendaman pada suhu $80{ }^{\circ} \mathrm{C}$ selama $3 \times 24$ jam + ethephon $1.2 \%$ + pemanasan kering selama 1 minggu), dan T5 (perendaman pada suhu $80{ }^{\circ} \mathrm{C}$ selama $3 \times 24$ jam + ethephon $1.6 \%+$ pemanasan kering selama 1 minggu). Tiap kombinasi perlakuan diulang sebanyak lima kali sehingga terdapat 25 satuan percobaan.

Pelaksanaan percobaan I adalah sebagai berikut. Benih yang digunakan terlebih dahulu direndam dalam air selama 7 hari untuk membersihkan kotoran, lalu dikering-anginkan selama 24 jam sebelum diberi perlakuan. Masing-masing perlakuan menggunakan 50 butir benih. Pemberian perlakuan dilakukan mula-mula dengan memanaskan air yang akan digunakan untuk perendaman hingga mencapai suhu masing-masing perlakuan. Benih kelapa sawit direndam dalam air panas sesuai dengan perlakuan intensitas perendaman. Waktu yang digunakan dalam satu kali perendaman yaitu 24 jam. Pada perendaman $2 \times 24$ jam dan $3 \times 24$ jam, dilakukan penggantian air panas tiap $24 \mathrm{jam}$. Setelah proses perendaman, benih dicuci menggunakan air lalu direndam dalam fungisida Dithane dengan konsentrasi $2 \mathrm{~g} \mathrm{l}^{-1}$ selama 5 menit, kemudian benih dikering-anginkan kembali selama 4 jam sebelum masuk ke ruang perkecambahan. Setelah itu benih diletakkan dalam tray perkecambahan dan diberi label lalu diletakkan di ruang inkubasi (ruang perkecambahan) selama 35 hari. Penyemprotan benih dilakukan setiap hari menggunakan fungisida Dithane dengan konsentrasi $2 \mathrm{~g}^{-1}$.

Percobaan II dilaksanakan sebagai berikut. Persiapan benih kelapa sawit dilakukan seperti pada percobaan I. Benih kelapa sawit diberi perlakuan perendaman dalam air panas berdasarkan hasil terbaik pada percobaan I. Benih dikering-anginkan terlebih dahulu selama 4 jam sebelum diberi perlakuan perendaman dalam berbagai konsentrasi ethephon selama 48 jam. Volume larutan ethephon yang digunakan untuk merendam 50 butir benih yaitu 200 $\mathrm{ml}$ (Herrera et al., 1998). Perendaman dilakukan menggunakan wadah plastik yang ditutup rapat. Setelah perendaman dalam ethephon, benih dicuci menggunakan air lalu direndam dalam fungisida Dithane dengan konsentrasi $2 \mathrm{~g}^{-1}$ selama 5 menit, kemudian benih dikering-anginkan kembali selama 4 jam sebelum masuk ke ruang perkecambahan.

Percobaan III dilakukan sebagai percobaan lanjutan dari percobaan I dan II. Pemanasan kering dilakukan pada akhir perlakuan untuk menurunkan kadar air benih sehingga diharapkan mampu meningkatkan perkcambahan dan menekan tingkat serangan cendawan. Pemanasan kering selama 1 minggu dilakukan pada pemrosesan ulang benih kelapa sawit yang belum tumbuh di PT Astra Agro Lestari Tbk. Benih mula-mula direndam dalam air suhu $80^{\circ} \mathrm{C}$ selama $3 \times 24$ jam. Benih dikering-anginkan terlebih dahulu selama 4 jam lalu direndam dalam berbagai konsentrasi ethephon selama 48 jam, setelah itu dikering-anginkan kembali selama 24 jam. Benih lalu dimasukkan ke dalam plastik lalu diikat dengan rapat dan dimasukkan ke dalam ruang pemanasan kering dengan suhu $39^{\circ} \mathrm{C}-40^{\circ} \mathrm{C}$ selama 1 minggu. Setelah 1 minggu, benih dicuci menggunakan air lalu direndam dalam fungisida Dithane dengan konsentrasi $2 \mathrm{~g} \mathrm{l}^{-1}$ selama 5 menit, kemudian benih dikeringanginkan kembali selama 4 jam sebelum masuk ke ruang perkecambahan.

Pengamatan terhadap kecambah kelapa sawit dilakukan setiap hari setelah inkubasi selama 35 hari. Pengamatan meliputi kecambah normal, abnormal, dan dorman. Pengamatan terhadap percobaan ini menggunakan beberapa tolok ukur yaitu kadar air benih (KA), daya berkecambah (DB), kecepatan tumbuh $\left(\mathrm{K}_{\mathrm{CT}}\right)$, potensi tumbuh maksimum $(\mathrm{PTM})$, intensitas dormansi (ID), dan persentase benih terserang cendawan.

\section{HASIL DAN PEMBAHASAN}

\section{Pengaruh Suhu Air dan Intensitas Perendaman terhadap Perkecambahan Benih Kelapa Sawit}

Berdasarkan hasil percobaan I didapat bahwa suhu air, intensitas perendaman, dan interaksi kedua perlakuan berpengaruh sangat nyata terhadap tolok ukur daya berkecambah, kecepatan tumbuh, potensi tumbuh maksimum, dan intensitas dormansi. Kedua perlakuan serta interaksinya tidak memberikan pengaruh nyata terhadap kadar air benih. Perlakuan intensitas perendaman berpengaruh sangat nyata terhadap persentase benih terserang cendawan namun perlakuan suhu air dan interaksi antara suhu air dan intensitas perendaman tidak berpengaruh nyata. Kadar air benih pada percobaan I berkisar antara $21.3 \%$ sampai $23.3 \%$.

Berdasarkan Tabel 1, perendaman selama 1x24 jam dalam berbagai suhu tidak mampu membuat benih berkecambah. Semakin tinggi intensitas perendaman, daya berkecambah benih semakin meningkat. Daya berkecambah meningkat hingga suhu $80^{\circ} \mathrm{C}$ lalu mengalami penurunan pada suhu $90^{\circ} \mathrm{C}$. Daya berkecambah tertinggi didapat pada perlakuan 
Tabel 1. Pengaruh suhu air dan intensitas perendaman terhadap persentase daya berkecambah benih kelapa sawit

\begin{tabular}{|c|c|c|c|}
\hline \multirow[t]{2}{*}{ Suhu Air } & \multicolumn{3}{|c|}{ Intensitas Perendaman } \\
\hline & $1 \times 24$ jam & $2 \times 24$ jam & $3 \times 24$ jam \\
\hline & & $\%$ & \\
\hline $27^{\circ} \mathrm{C}$ & $0.71 \mathrm{~g}(0.0)$ & $0.71 \mathrm{~g} \quad(0.0)$ & $0.71 \mathrm{~g}$ \\
\hline $60{ }^{\circ} \mathrm{C}$ & $0.71 \mathrm{~g}(0.0)$ & $0.72 \mathrm{fg}(1.3)$ & $0.77 \mathrm{c}$ \\
\hline $70{ }^{\circ} \mathrm{C}$ & $0.71 \mathrm{~g}(0.0)$ & $0.73 \mathrm{ef}(3.3)$ & $0.76 \mathrm{~cd} \quad(7.3)$ \\
\hline $80{ }^{\circ} \mathrm{C}$ & $0.71 \mathrm{~g}(0.0)$ & $0.74 \mathrm{de}(5.3)$ & $0.82 \mathrm{a} \quad(16.7)$ \\
\hline $90{ }^{\circ} \mathrm{C}$ & $0.71 \mathrm{~g}(0.0)$ & 0.73 ef (3.3) & $0.78 \mathrm{~b} \quad(11.3)$ \\
\hline
\end{tabular}

Keterangan: Angka rataan yang diikuti oleh huruf yang sama tidak berbeda nyata berdasarkan uji DMRT 5\%. Data yang dianalisis adalah data yang sudah ditransformasi $\sqrt{ }(x+0.5)$. Angka dalam kurung merupakan data asli sebelum ditransformasi ; $\mathrm{kk}=1.36 \%$

perendaman dalam suhu $80^{\circ} \mathrm{C}$ selama $3 \times 24$ jam yaitu sebesar $16.7 \%$. Perlakuan ini kemudian digunakan pada percobaan II sebelum benih direndam dalam ethephon.

Pada intensitas perendaman $2 \times 24$ jam dan $3 \times 24$ jam, terjadi peningkatan kecepatan tumbuh (Tabel 2) dan potensi tumbuh maksimum benih (Tabel 3) hingga suhu $80^{\circ} \mathrm{C}$ lalu mengalami penurunan pada suhu $90^{\circ} \mathrm{C}$. Peningkatan kecepatan tumbuh dan potensi tumbuh maksimum juga terjadi pada intensitas perendaman yang lebih tinggi. Kecepatan tumbuh tertinggi didapat pada perlakuan perendaman dalam suhu $80^{\circ} \mathrm{C}$ selama $3 \times 24$ jam yaitu sebesar $0.59 \% \mathrm{KN}$ etmal $^{-1}$ dengan potensi tumbuh maksimum sebesar $16.7 \%$. Perendaman selama $3 \times 24$ jam menurunkan persentase benih terserang cendawan dari $56.8 \%$ menjadi $22.5 \%$ dibanding pada perendaman $1 \times 24$ jam (data tidak ditampilkan).

\section{Pengaruh Konsentrasi Ethephon terhadap Perkecambahan Benih Kelapa Sawit}

Konsentrasi ethephon berpengaruh sangat nyata terhadap kadar air (KA), daya berkecambah (DB), kecepatan tumbuh $\left(\mathrm{K}_{\mathrm{CT}}\right)$, potensi tumbuh maksimum (PTM), dan intensitas dormansi (ID). Konsentrasi ethephon tidak berpengaruh nyata terhadap persentase benih terserang cendawan. Kadar air benih, daya berkecambah, dan kecepatan tumbuh cenderung menurun pada konsentrasi ethephon yang lebih tinggi. Potensi tumbuh maksimum meningkat hingga konsentrasi $0.4 \%$ yaitu sebesar $29.2 \%$ lalu menurun pada konsentrasi ethephon yang lebih tinggi.
Tabel 2. Pengaruh suhu air dan intensitas perendaman terhadapkecepatantumbuhbenihkelapa sawit

\begin{tabular}{|c|c|c|c|}
\hline \multirow{2}{*}{$\begin{array}{l}\text { Suhu } \\
\text { Air }\end{array}$} & \multicolumn{3}{|c|}{ Intensitas Perendaman } \\
\hline & $1 \times 24$ jam & $2 \times 24$ jam & $3 \times 24$ jam \\
\hline & & $\% \mathrm{KN}$ etmal- 1. & \\
\hline $27^{\circ} \mathrm{C}$ & $0.7071 \mathrm{~g}(0.00)$ & $0.7071 \mathrm{~g} \quad(0.00)$ & $0.7071 \mathrm{~g} \quad(0.00)$ \\
\hline $60^{\circ} \mathrm{C}$ & $0.7071 \mathrm{~g}(0.00)$ & 0.7074 fg $(0.04)$ & $0.7093 \mathrm{c} \quad(0.32)$ \\
\hline $70^{\circ} \mathrm{C}$ & $0.7071 \mathrm{~g}(0.00)$ & 0.7079 ef $(0.12)$ & $0.7090 \mathrm{~cd}(0.27)$ \\
\hline $80^{\circ} \mathrm{C}$ & $0.7071 \mathrm{~g}(0.00)$ & $0.7084 \mathrm{de}(0.18)$ & $0.7112 \mathrm{a} \quad(0.59)$ \\
\hline $90^{\circ} \mathrm{C}$ & $0.7071 \mathrm{~g}(0.00)$ & $0.7078 \mathrm{efg}(0.11)$ & $0.7101 \mathrm{~b} \quad(0.43)$ \\
\hline
\end{tabular}

Keterangan: Angka rataan yang diikuti oleh huruf yang sama tidak berbeda nyata berdasarkan uji DMRT 5\%. Data yang dianalisis adalah data yang sudah ditransformasi $\sqrt{ }(\mathrm{x}+0.5)$. Angka dalam kurung merupakan data asli sebelum ditransformasi ; $\mathrm{kk}=0.06 \%$

Nilai intensitas dormansi menurun hingga konsentrasi ethephon $0.4 \%$ yaitu sebesar $70.8 \%$ lalu meningkat pada konsentrasi ethephon yang lebih tinggi. Persentase benih terserang cendawan berkisar antara $12.8 \%$ sampai $16.0 \%$ (Tabel 4).

Pengaruh Perendaman dalam Berbagai Konsentrasi Ethephon yang Didahului dengan Perendaman dalam Air Panas $80^{\circ} \mathrm{C}$ Selama $3 \times 24$ Jam dan Diakhiri dengan Pemanasan Kering selama 1 Minggu terhadap Perkecambahan Benih Kelapa Sawit

Perlakuan pematahan dormansi berpengaruh sangat nyata terhadap kadar air, daya berkecambah, kecepatan tumbuh, dan potensi tumbuh maksimum

Tabel 3. Pengaruh suhu air dan intensitas perendaman terhadap potensi tumbuh maksimum benih kelapa sawit

\begin{tabular}{|c|c|c|c|}
\hline \multirow[t]{2}{*}{ Suhu Air } & \multicolumn{3}{|c|}{ Intensitas Perendaman } \\
\hline & $1 \times 24$ jam & $2 \times 24$ jam & $3 \times 24$ jam \\
\hline & \multicolumn{3}{|c|}{$\ldots \%$} \\
\hline $27^{\circ} \mathrm{C}$ & $0.7071 \mathrm{f}(0.0)$ & $0.7071 \mathrm{f} \quad(0.0)$ & $0.7071 \mathrm{f} \quad(0.0)$ \\
\hline $60^{\circ} \mathrm{C}$ & $0.7071 \mathrm{f}(0.0)$ & $0.7164 \mathrm{ef}(1.3)$ & $0.7658 \mathrm{c} \quad(8.7)$ \\
\hline $70^{\circ} \mathrm{C}$ & $0.7071 \mathrm{f}(0.0)$ & $0.7303 \mathrm{e} \quad(3.3)$ & $0.7571 \mathrm{~cd}(7.3)$ \\
\hline $80^{\circ} \mathrm{C}$ & $0.7071 \mathrm{f}(0.0)$ & $0.7483 d \quad(6.0)$ & $0.8164 \mathrm{a} \quad(16.7)$ \\
\hline $90^{\circ} \mathrm{C}$ & $0.7071 \mathrm{f}(0.0)$ & $0.7303 \mathrm{e} \quad(3.3)$ & $0.7873 b(12.0)$ \\
\hline Keterangan: & $\begin{array}{l}\text { Angka rataan y } \\
\text { nyata berdasarl } \\
\text { datayang sudal } \\
\text { merupakan da }\end{array}$ & $\begin{array}{l}\text { ansformasi } \sqrt{ }(x+ \\
\text { li sebelum ditra }\end{array}$ & $\begin{array}{l}\text { ang sama tidak berb } \\
\text { yang dianalisis ada } \\
\text { 5). Angka dalam kur } \\
\text { sformasi : } \mathrm{kk}=1.2\end{array}$ \\
\hline
\end{tabular}


Tabel 4. Pengaruh konsentrasi ethephon terhadap KA, DB, $\mathrm{K}_{\mathrm{CT}}$, PTM, ID, dan persentase benih kelapa sawit terserang cendawan

\begin{tabular}{llccccc}
\hline $\begin{array}{c}\text { Konsentrasi Ethephon } \\
(\%)\end{array}$ & $\begin{array}{l}\text { KA } \\
(\%)\end{array}$ & $\begin{array}{c}\text { DB } \\
(\%)\end{array}$ & $\begin{array}{c}\text { KCT } \\
(\% \text { etmal-1) }\end{array}$ & $\begin{array}{c}\text { PTM } \\
(\%)\end{array}$ & $\begin{array}{c}\text { ID } \\
(\%)\end{array}$ & $\begin{array}{c}\text { Benih Terserang } \\
\text { Cendawan } \\
(\%)\end{array}$ \\
\hline 0 & $21.7 \mathrm{a}$ & $0.802 \mathrm{a}(14.4)$ & $0.7107 \mathrm{a}(0.51)$ & $14.4 \mathrm{c}$ & $85.6 \mathrm{a}$ & 16 \\
0.4 & $20.8 \mathrm{ab}$ & $0.713 \mathrm{~b}(0.8)$ & $0.7073 \mathrm{~b}(0.04)$ & $29.2 \mathrm{a}$ & $70.8 \mathrm{c}$ & 12.8 \\
0.8 & $19.6 \mathrm{c}$ & $0.707 \mathrm{~b}(0.0)$ & $0.7071 \mathrm{~b}(0.00)$ & $20.0 \mathrm{~b}$ & $80.0 \mathrm{~b}$ & 16 \\
1.2 & $19.9 \mathrm{bc}$ & $0.707 \mathrm{~b}(0.0)$ & $0.7071 \mathrm{~b}(0.00)$ & $23.2 \mathrm{~b}$ & $76.8 \mathrm{~b}$ & 13.6 \\
1.6 & $20.0 \mathrm{bc}$ & $0.707 \mathrm{~b}(0.0)$ & $0.7071 \mathrm{~b}(0.00)$ & $20.4 \mathrm{~b}$ & $79.6 \mathrm{~b}$ & 13.2 \\
\hline
\end{tabular}

Keterangan : Angka rataan yang diikuti huruf yang sama pada kolom yang sama tidak berbeda nyata menurut statistik uji lanjut DMRT pada taraf $\alpha=5 \%$. Angka dalam kurung meru-pakan data asli sebelum ditransformasi $\sqrt{ }(x+0.5)$

(Tabel 5). Konsentrasi ethephon tidak berpengaruh nyata terhadap intensitas dormansi dan persentase benih terserang cendawan. Kadar air benih, daya berkecambah, dan kecepatan tumbuh cenderung menurun pada konsentrasi ethephon yang lebih tinggi. Potensi tumbuh maksimum meningkat hingga konsentrasi ethephon $0.4 \%$ (T2) yaitu sebesar $52.0 \%$ lalu cenderung menurun pada konsentrasi ethephon yang lebih tinggi. Nilai intensitas dormansi berkisar antara $56.4 \%$ sampai $66.4 \%$, sedangkan persentase benih terserang cendawan berkisar antara 13.6\% sampai $16.4 \%$.

Benih kelapa sawit merupakan benih yang membutuhkan kadar air di atas $18 \%$ untuk dapat berkecambah (Adiguno, 1998). Pada percobaan I, perlakuan meningkatkan kadar air benih, sedangkan pada percobaan II dan III menurunkan kadar air benih. Hal ini diduga karena pada percobaan I menggunakan bahan perendam air yang memiliki kepekatan sama, sedangkan pada percobaan II dan III menggunakan bahan perendam ethephon dalam berbagai konsentrasi yang memiliki kepekatan berbeda. Semakin pekat larutan perendam, semakin sulit imbibisi ke dalam benih. Hal ini dikarenakan kerasnya kulit benih yang mengandung lignin menjadi penghalang masuknya air (Nurmailah, 1999).

Kadar air benih berhubungan erat dengan persentase benih terserang cendawan. Persentase benih terserang cendawan pada percobaan I cenderung lebih tinggi dibanding percobaan II dan III. Cendawan banyak menyerang benih yang memiliki kadar air yang lebih tinggi. Cendawan yang menyerang pada percobaan I tidak mampu diidentifikasi karena hasil mikroskopis tidak menunjukkan struktur khusus yang mencirikan salah satu jenis cendawan, sedangkan cendawan yang menyerang pada percobaan II dan III adalah Aspergillus sp.

Pada percobaan I, daya berkecambah, kecepatan tumbuh, dan potensi tumbuh maksimum yang dihasilkan masih sangat rendah. Peningkatan intensitas perendaman meningkatkan daya berkecambah, kecepatan tumbuh, dan potensi tumbuh

Tabel 5. Pengaruh perendaman dalam berbagai konsentrasi ethephon yang didahului dengan perendaman dalam air panas suhu $80^{\circ} \mathrm{C}$ selama $3 \times 24$ jam dan diakhiri dengan pemanasan kering selama 1 minggu terhadap $\mathrm{KA}, \mathrm{DB}, \mathrm{K}_{\mathrm{CT}}$, PTM, ID, dan persentase benih kelapa sawit terserang cendawan

\begin{tabular}{lcccccc}
\hline Perlakuan & $\begin{array}{c}\text { KA } \\
(\%)\end{array}$ & $\begin{array}{c}\text { DB } \\
(\%)\end{array}$ & $\begin{array}{c}\text { KCT } \\
(\% \text { etmal-1) }\end{array}$ & $\begin{array}{c}\text { PTM } \\
(\%)\end{array}$ & $\begin{array}{c}\text { ID } \\
(\%)\end{array}$ & $\begin{array}{c}\text { Benih Terserang } \\
\text { Cendawan }(\%)\end{array}$ \\
\hline T1 & $19.5 \mathrm{a}$ & $0.914 \mathrm{a}(33.6)$ & $0.7193 \mathrm{a}(1.75)$ & $33.6 \mathrm{~d}$ & 66.4 & 16.4 \\
$\mathrm{~T} 2$ & $18.8 \mathrm{ab}$ & $0.729 \mathrm{~b}(3.2)$ & $0.7083 \mathrm{~b}(0.17)$ & $52.0 \mathrm{a}$ & 61.6 & 13.6 \\
$\mathrm{~T} 3$ & $17.9 \mathrm{c}$ & $0.707 \mathrm{c}(0.0)$ & $0.7071 \mathrm{c}(0.00)$ & $43.6 \mathrm{~b}$ & 56.4 & 15.2 \\
$\mathrm{~T} 4$ & $18.2 \mathrm{bc}$ & $0.707 \mathrm{c}(0.0)$ & $0.7071 \mathrm{c}(0.00)$ & $39.6 \mathrm{c}$ & 60.4 & 13.6 \\
$\mathrm{~T} 5$ & $18.2 \mathrm{bc}$ & $0.707 \mathrm{c}(0.0)$ & $0.7071 \mathrm{c}(0.00)$ & $36.4 \mathrm{~cd}$ & 63.6 & 14 \\
\hline
\end{tabular}

Keterangan : Angka rataan yang diikuti huruf yang sama pada kolom yang sama tidak berbeda nyata menurut statistik uji lanjut DMRT pada taraf $\alpha=5 \%$. Angka dalam kurung merupakan data asli sebelum ditransformasi $\sqrt{(x+0.5)}$ 
maksimum. Peningkatan suhu air juga mempengaruhi perkecambahan benih kelapa sawit, semakin tinggi suhu air maka daya berkecambah benih semakin meningkat hingga mencapai maksimum $16.7 \%$ pada suhu $80^{\circ} \mathrm{C}$ dan mengalami penurunan pada suhu $90^{\circ} \mathrm{C}$. Penurunan pada suhu $90^{\circ} \mathrm{C}$ dapat terjadi karena tiap spesies memiliki respon tersendiri terhadap temperatur. Agba et al. (2005) melaporkan bahwa perendaman benih Mucuna flagellipes pada air suhu $60^{\circ} \mathrm{C}$ selama 10 menit memberikan hasil yang lebih baik dibanding perendaman dalam suhu $80^{\circ} \mathrm{C}$ dan $100^{\circ} \mathrm{C}$. Menurut Crocker dan Barton (1953), temperatur suhu tertentu dapat menyebabkan terjadinya disintegrasi lapisan kulit benih sehingga membuat benih permeabel terhadap air, namun pada suhu air yang terlalu tinggi diasumsikan perendaman tidak hanya melarutkan lapisan kutikula di sekitar kulit benih, tetapi bagian dalam benih seperti embrio atau kotiledon juga dapat ikut terlarut dalam air.

Penggunaan ethephon pada percobaan II dan III meningkatkan persentase benih yang berkecambah dibanding percobaan I. Hal ini karena penambahan ethephon meningkatkan ketersediaan etilen yang mampu merangsang perkecambahan benih. Gong dan Bewley (2007) mengemukakan bahwa penipisan dinding sel endosperma dipengaruhi oleh beberapa enzim, salah satunya adalah enzim endo$\beta$-mannanase. Berdasarkan penelitian Nascimento et al. (2000), penambahan etilen pada benih selada mampu meningkatkan enzim endo- $\beta$-mannanase. Gong dan Bewley (2007) mengemukakan bahwa penipisan dinding sel endosperma dipengaruhi oleh beberapa enzim, salah satunya adalah enzim endo$\beta$-mannanase. Menurut Matilla dan Matilla-Vazquez (2008), peningkatan enzim endo- $\beta$-mannanase mampu menipiskan dinding sel endosperma sehingga radikula dapat muncul dan mematahkan dormansi benih.

Pada percobaan II dan III, perendaman dalam ethephon menurunkan daya berkecambah dan kecepatan tumbuh, hasil terbaik ditunjukkan pada perendaman pada konsentrasi ethephon $0 \%$. Potensi tumbuh maksimum memberikan hasil yang berbeda. Hasil yang lebih tinggi didapat pada konsentrasi ethephon $0.4 \%$ dan menurun pada konsentrasi yang lebih tinggi. Hal ini terjadi karena banyaknya kecambah yang tumbuh tidak normal pada perendaman menggunakan ethephon konsentrasi $0.4 \%$ sampai 1.6\%. Berdasarkan hasil penelitian Wan dan Hor (1983), penggunaan ethephon $0.1 \%$ dan $0.2 \%$ tidak mampu mematahkan dormansi benih kelapa sawit. Herrera et al. (1998) melaporkan bahwa perendaman dalam ethephon $1.2 \%$ menghasilkan $60 \%$ benih kelapa sawit yang berkecambah, namun benih banyak yang tumbuh tidak normal. Johnston (1977) mengemukakan bahwa pada konsentrasi ethephon yang semakin tinggi, kandungan morphactin dalam benih juga semakin besar. Morphactin merupakan senyawa yang dikenal sebagai penghambat pertumbuhan, terutama menghambat pertumbuhan radikula. Hal ini yang menyebabkan banyaknya kecambah abnormal. Percobaan III (PTM 52.0\%) memberikan hasil yang lebih baik dibanding percobaan II (PTM 29.2\%). Hal ini dikarenakan adanya pemanasan kering selama 1 minggu di akhir perlakuan. Menurut Hussey (1958), metode pemanasan kering mampu merangsang perkecambahan benih kelapa sawit.

\section{KESIMPULAN}

Perlakuan perendaman benih dalam air suhu $80^{\circ} \mathrm{C}$ selama $3 \times 24$ jam meningkatkan perkecambahan benih kelapa sawit dibanding kontrol, sedangkan perlakuan perendaman air panas yang dikombinasikan dengan perendaman menggunakan ethephon 0.4-1.6\% menurunkan daya berkecambah karena banyaknya kecambah yang tumbuh tidak normal. Perendaman dalam ethephon $0.4 \%$ yang didahului dengan perendaman dalam air panas $80^{\circ} \mathrm{C}$ selama $3 \times 24$ jam dan diakhiri dengan pemanasan kering selama 1 minggu mampu menghasilkan potensi tumbuh maksimum benih sebesar $52.0 \%$ namun belum efektif untuk mematahkan dormansi benih kelapa sawit.

\section{UCAPAN TERIMA KASIH}

Penulis menyampaikan terima kasih kepada PT Gunung Sejahtera Ibu Pertiwi, Astra Agro Lestari, Tbk. atas dukungannya terhadap pelaksanaan penelitian ini.

\section{DAFTAR PUSTAKA}

Adiguno, S. 1998. Pengadaan dan pengawasan mutu internal kecambah kelapa sawit di PT Socfindo-Medan, Sumatera Utara. Laporan Keterampilan Profesi. Jurusan Budidaya Pertanian. IPB. Bogor.

Agba, O.A, J.E. Asiegbu, C.P.E Omaliko. 2005. Effect of length of soaking in water at room temperature and hot water treatment on the germination of Mucuna flagellipes (vogel ex hook) seeds. Agr. Sci. 4(1):15-18.

Ani, N. 2006. Pengaruh perendaman benih dalam air panas terhadap daya berkecambah dan pertumbuhan bibit lamtoro (Leucaena 
leucocephala). Jurnal Penelitian Bidang Ilmu Pertanian 4(1):24-28.

Crocker, W, L. Barton. 1953. Physiology of Seeds: An Introduction to the Experimental Study of Seeds and Germination Problems. Chronica Botanica Company. New York.

Gong, X., J.D. Bewley. 2007. Endo- $\beta$-mannase genes and their encoded proteins in tomato. Seed Sci. Res. 17:143-154.

Herrera, J, A. Alizaga, E. Guevara. 1998. Use of chemical treatments to induce seed germination in oil palm (Elaeis guineensis Jacq.). ASD Oil Palm Papers 18:1-16.

Hussey, G. 1958. An analysis of the factors controlling the germination of the seed of oil palm. Ann. Bot. 22:259-284.

Johnston, M.E.H. 1977. Germination of Seed. Centre of Agricultural Publishing and Documentation. Wageningen.

Kesaulija, E.M. 1979. Pengaruh perendaman pada berbagai suhu airterhadap nilaiperkecambahan biji Casuarina equisetifolia Lum. Skripsi. Jurusan Kehutanan. Fakultas Peternakan dan Kehutanan. Universitas Negeri Cendrawasih. Manokwari.
Khaeruddin. 1994. Pembibitan Tanaman Hutan Tanaman Industri. Penebar Swadaya. Jakarta.

Matilla, A.J., M.A. Matilla-Vazquez. 2008. Involvement of ethylene in seed physiology. Plant Sci. 175:87-97.

Nascimento, W.M., D.J. Cantliffe, D.J. Hubber. 2005. Seed aging affects ethylene production and endo- $\beta$-mannase activity during lettuce seed germination at high temperature. Seed Sci. Technol. 33:11-17.

Nurmailah, E.S. 1999. Pengaruh matriconditioning plus inokulasi dengan Trichoderma sp. terhadap perkecambahan, kadar lignin, dan asam absisat benih kelapa sawit (Elaeis guineensis Jacq.). Skripsi. Jurusan Budi Daya Pertanian. Fakultas Pertanian. Institut Pertanian Bogor. Bogor.

Wan, C.K., H.L. Hor. 1983. A study on the effects of certain growth substances on germination of oil palm (Elaeis guineensis Jacq) seeds. Pertanika 6(2):45-48. 